\title{
Secretome Analysis of Skeletal Myogenesis Using SILAC and Shotgun Proteomics
}

\author{
C. Y. X'avia Chan, ${ }^{1,2}$ John C. McDermott, ${ }^{1,2,3,4}$ and K. W. Michael Siu' ${ }^{1,2,5}$ \\ ${ }^{1}$ Department of Biology, York University, 4700 Keele Street, Toronto, ON, Canada M3J 1P3 \\ ${ }^{2}$ Centre for Research in Mass Spectrometry (CRMS), York University, 4700 Keele Street, Toronto, ON, Canada M3J 1P3 \\ ${ }^{3}$ Muscle Health Research Centre (MHRC), York University, 4700 Keele Street, Toronto, ON, Canada M3J 1P3 \\ ${ }^{4}$ Centre for Research in Biomolecular Interactions (CRBI), York University, 4700 Keele Street, Toronto, ON, Canada M3J 1P3 \\ ${ }^{5}$ Department of Chemistry, York University, 4700 Keele Street, Toronto, ON, Canada M3J 1P3
}

Correspondence should be addressed to John C. McDermott, jmcderm@yorku.ca and K. W. Michael Siu, kwmsiu@yorku.ca

Received 15 November 2010; Accepted 26 January 2011

Academic Editor: Uwe Völker

Copyright ( 92011 C. Y. X'avia Chan et al. This is an open access article distributed under the Creative Commons Attribution License, which permits unrestricted use, distribution, and reproduction in any medium, provided the original work is properly cited.

\begin{abstract}
Myogenesis, the formation of skeletal muscle, is a multistep event that commences with myoblast proliferation, followed by cell-cycle arrest, and finally the formation of multinucleated myotubes via fusion of mononucleated myoblasts. Each step is orchestrated by well-documented intracellular factors, such as cytoplasmic signalling molecules and nuclear transcription factors. Regardless, the key step in getting a more comprehensive understanding of the regulation of myogenesis is to explore the extracellular factors that are capable of eliciting the downstream intracellular factors. This could further provide valuable insight into the acute cellular response to extrinsic cues in maintaining normal muscle development. In this paper, we survey the intracellular factors that respond to extracellular cues that are responsible for the cascades of events during myogenesis: myoblast proliferation, cell-cycle arrest of myoblasts, and differentiation of myoblasts into myotubes. This focus on extracellular perspective of muscle development illustrates our mass spectrometry-based proteomic approaches to identify differentially expressed secreted factors during skeletal myogenesis.
\end{abstract}

\section{Introduction}

Myogenesis, the formation of skeletal muscle, has been recognized as a hierarchical cellular event, commencing with myogenic lineage specification and followed by iterative proliferation of the muscle precursor cells called myoblasts in which cell-cell contact is initiated. This triggers withdrawal of myoblasts from the proliferation cycle (i.e., cell-cycle arrest) and in turn switches on the differentiation program in which mononucleated myoblasts are fused to each other and give rise to multinucleated myotubes (i.e., building blocks for contractile muscle fibres in the mature animal). Each step is orchestrated by groups of intracellular factors, such as cytoplasmic signalling molecules and nuclear transcription factors, which are described in further detail below.

1.1. Myogenic Lineage Specification. Skeletal muscle originates from the paraxial mesoderm, epithelialization and segmentation of which gives rise to the somites in a cranio-caudal manner (i.e., somites are generated and specified from head to tail) (Figure 1). Various compartments of the somite are committed to distinct cell lineages: myotome (muscle), dermatome (skin), and sclerotome (bone and cartilage), according to their relative orientations to the surrounding tissue, such as ectoderm, neural tube, notochord, and lateral mesoderm [1]. The ventral medial portion of the somite is specified as the sclerotome, whereas the doublelayered structure remaining is called the dermomyotome which gives rise to the dermatome and myotome. The latter is subdivided into two compartments: dorsal medial lip (DML) and ventral lateral lip (VLL). The former compartment gives rise to the epaxial myotome that becomes the back muscle, whereas the latter gives the hypaxial myotome that generates the muscles of the body wall, limbs, and tongue [2-5].

1.2. Myoblast Proliferation with Simultaneous Repression of Muscle Differentiation. After the primary wave of myoblasts 


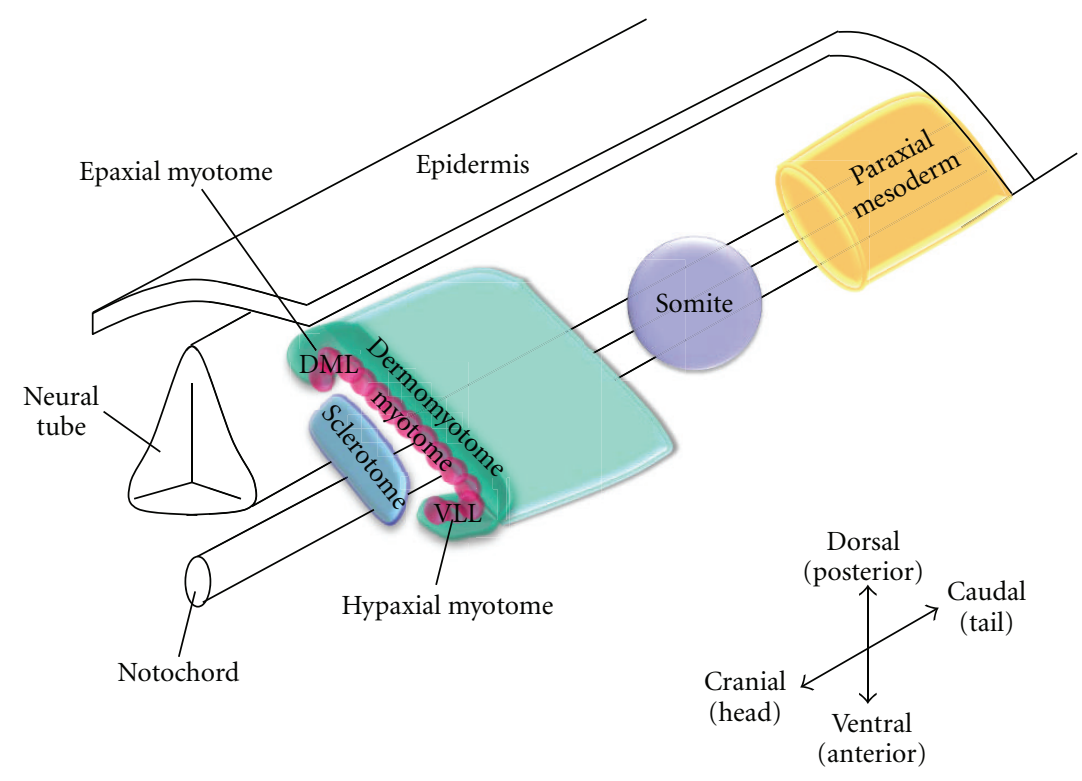

FIgure 1: Myogenic lineage specification. Dorsal medial lip and ventral lateral lip were denoted as DML and VLL, respectively. Redrawn from Buckingham et al. [6].

is generated from the somite, they enter the cell cycle and undergo iterative propagation to expand the cell population, eventually cell-cell contact occurs. This step has been shown to be essential to withdraw the myoblasts from the proliferation cycle and initiate the differentiation program (Figure 2(a)) [7-9]. Thus, the proliferation and differentiation of myoblasts are mutually exclusive events; the tipping point between the two is governed by a master regulator: the retinoblastoma protein $(\mathrm{pRb})$ [10-12].

During proliferation, cyclin/cyclin-dependent kinases (CDKs), such as cyclin $\mathrm{D} / \mathrm{cdk} 4$, cyclin $\mathrm{D} / \mathrm{cdk} 6$, cyclin $\mathrm{E} / \mathrm{cdk} 2$, and cyclin $\mathrm{A} / \mathrm{cdk} 2$, are active. These kinases phosphorylate $\mathrm{pRb}$, holding it inactive [13-18]. As a result, $\mathrm{pRb}$ is unable to bind to the E2F transcription factor complex and inhibit its activation of downstream proliferation-associated cellular events, including chromosome segregation, mitotic spindle formation, and chromatin remodelling [19] (Figure 2(b)).

Notably, the differentiation of these myoblasts is critically dependent upon a family of myogenic transcription factors: the myogenic regulatory factors (MRFs), including myogenic differentiation factor (MyoD) $[20,21]$ and myogenic factor 5 (Myf5) $[22,23]$. The MRFs confer on the myoblasts a potent ability to differentiate. By contrast, mitogenic myoblasts may be prohibited from differentiation by myogenic repressors, including Id [24, 25], twist [26-28], MyoR [29, 30], Mist 1 [31], and I-mf [32]. In the absence of myogenic repressors, MRFs, which are members of the class II basic helix-loophelix (bHLH) superfamily, can dimerize with members of the class I bHLH family, the E proteins. The E protein: MRF heterodimer thus resulted recognizes and binds to the consensus DNA sequence (CANNTG) named the Ebox, which lies upstream of most muscle-specific genes, for example, the myosin heavy chain and muscle creatine kinase [33]. Conversely, in the presence of myogenic repressors, the dimerization between MRF and the E protein inside the nucleus is negated either by (1) competitive binding to MRFs or the E proteins by means of Id, twist, MyoR, and Mist 1, or (2) sequestering MRFs in the cytoplasm by means of I-mf. Additional control can come via other interactions, including those of $\mathrm{pRb}$ and CDKs which can also phosphorylate MRFs and subject them to degradation [34-36] (Figure 2(b)). The initial repression of muscle differentiation is essential for ensuring a sufficiently large number of myoblasts are attained prior to differentiation to populate the vast amount of skeletal musculature in the metazoan species.

1.3. Cell-Cycle Arrest of Myoblasts with Simultaneous Activation of Muscle Differentiation. Under growth conditions, myoblasts proliferate until they reach confluency and cellcell contact provokes growth arrest. The switch between cell-cell contact and cell-cycle arrest is mediated by transmembrane proteins, such as $\mathrm{m}$-cadherin [37-42]. Upon cell-cell contact, $\mathrm{m}$-cadherin is activated and induces CDK inhibitors (CDKIs), for example, p21 and p57 [43, 44]. As the name suggests, CDKIs inhibit CDK from phosphorylating its respective substrates, such as $\mathrm{pRb}$ and $\operatorname{MRF}[45,46]$. As a result, both $\mathrm{pRb}$ and $\mathrm{MyoD}$ are spared from degradation. The corollary to that is twofold: (1) nonphosphorylated pRb can bind and inhibit E2F from activating the downstream proliferation events, by which cell-cycle arrest of myoblasts is achieved [47, 48]; (2) nonphosphorylated MyoD can dimerize with the $\mathrm{E}$ protein and cooperatively bind to the $\mathrm{E}$ box to activate the expression of muscle-specific gene, thus triggering the differentiation program. Furthermore, with the recruitment of myogenic coactivators, such as myocyte enhancer factor 2 (MEF2) [49-52] as well as the chromatin remodelling factors, the histone acetyltransferases (HATs), for example, p300 and p300/CBP-associated factor (PCAF) [53-62], the differentiation program is initiated (Figure 2(c)). In addition, activated cadherin interacts and 


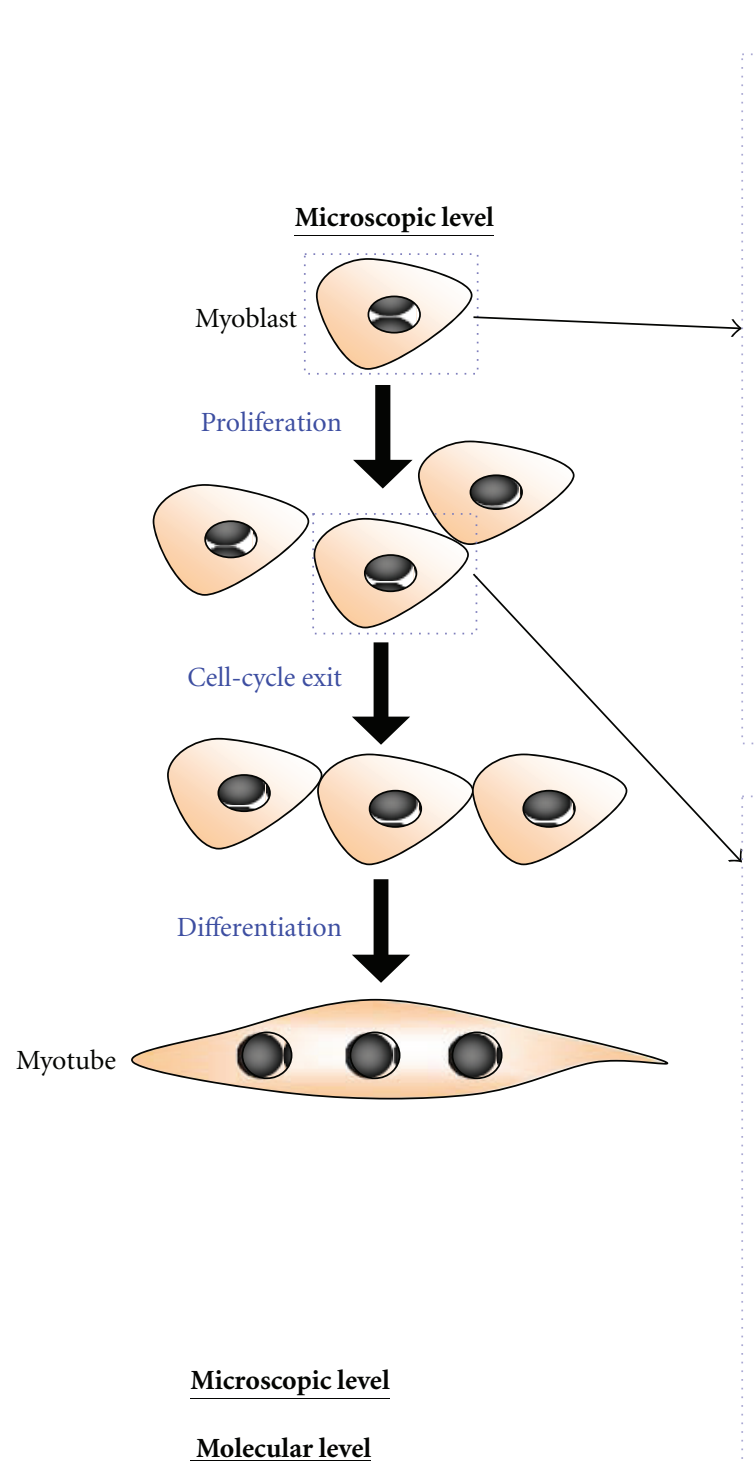

(a)

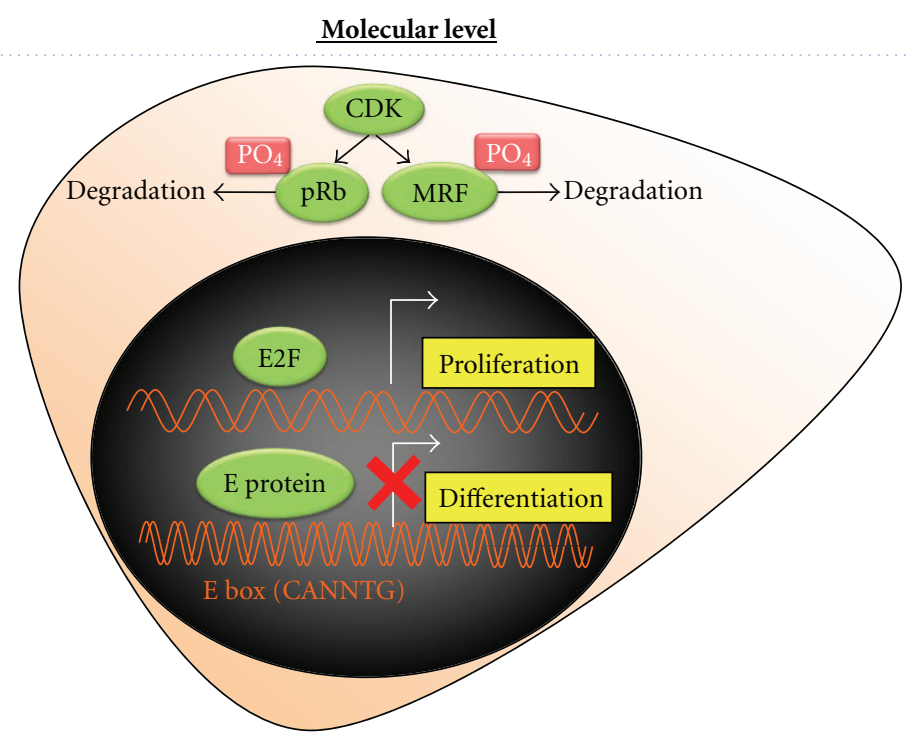

(b)

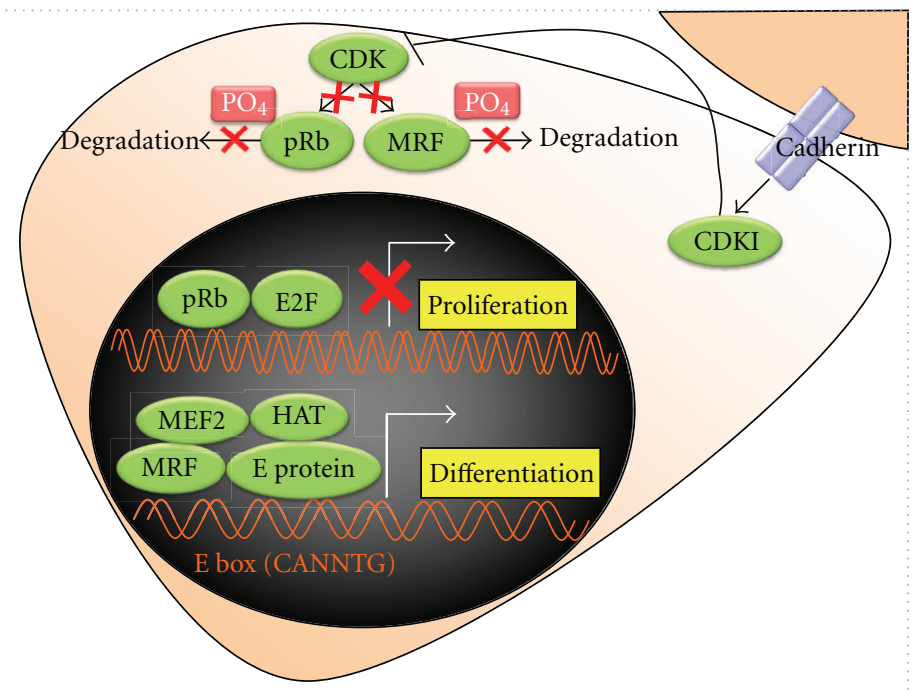

(c)

FIGURE 2: Skeletal muscle differentiation at the microscopic and molecular level. (a) During myogenesis, mononucleated myoblast proliferate, followed by cell-cycle exit, and fusion to form multinucleated myotube; (b) during proliferation, at the molecular level, active CDK could trigger myoblast proliferation by phosphorylating and subjecting pRb to degradation, in which E2F transcription factor is free from the inhibitory effect of $\mathrm{pRb}$ and elicits the proliferation of myoblasts. Simultaneously, CDK can also block myoblasts from differentiation via the phosphorylation-induced degradation of MRF. As a consequence, E protein by itself cannot drive the differentiation program; (c) upon cell-cell contact, m-cadherin is activated, by which CDKI is induced. This in turn inhibits CDK from phosphorylating its downstream substrates: $\mathrm{pRb}$ and MRF. Hence, both $\mathrm{pRb}$ and MRF are exempted from degradation, in which the former can withdraw the myoblasts from the cell cycle by inhibiting E2F transcription factor from activating the proliferation-associated events, whereas the latter complexes with E protein, myogenic co-activator MEF2, and the chromatin remodeling molecule HATs, in an effort to evoke the differentiation program of myoblasts synergistically. Phosphate groups were indicated as " $\mathrm{PO}_{4}$ ".

triggers a cell adhesion molecule of the Ig superfamily called CAM-related/downregulated by oncogenes (CDO) $[63,64]$. The CDO complex promotes myogenesis by activating the p38 MAPK signalling pathway [65-68], which is a wellknown promyogenic signal acting at various steps [69-71]. p38, for example, enhances the activity of MyoD [72], and its co-activator MEF2 [73], favouring MyoD/E protein heterodimerization by phosphorylating E protein [74], recruiting SWI-SNF chromatin-remodelling complex to the promoter of muscle-specific genes to enhance accessibility to transcriptional regulators required for subsequent gene expression [75]. Intriguingly, CDO is a target of MyoD, 
establishing positive feedback loop which reinforces the muscle differentiation program $[64,76]$.

1.4. From Intra- to Extracellular Perspective of Myogenesis. Irrespective of well-documented intracellular factors entailed in myogenesis, the key step in developing a more comprehensive picture of the regulation of muscle development is to investigate the extracellular factors that prime these downstream intracellular events. This, in turn, may provide valuable insight into the acute cellular response as a result of extrinsic cues in normal muscle development and regeneration. Intriguingly, the effects exerted by the "conditioned" media (CM) on the development of muscle cells have been documented some time ago [77, 78], illustrating the phenomena that myogenic cells modify their own extracellular milieu by secreting factors that exert autocrine and paracrine effects on the differentiation program. Furthermore, the skeletal muscle has been recognized as the largest endocrine organ in humans for secreting extracellular factors, the myokines that orchestrate muscle development in an autocrine fashion [79, 80]. Apart from the well-known myokines, such as members of the insulin-like growth factor1 (IGF1) [81-90] and transforming growth factor (TGF) families [91-99], which have potent, but opposing effects on myogenesis, there were individual studies investigating other myokines, such as plasminogen activator [100], collagenase [101], decorin [102], glial growth factor [103], neurocrescin [104], meltrin alpha [105], musculin [79, 106], interleukin-1 beta [107], interleukin-7 [108], ADAMTSlike 2 [109], follistatin-like 1 [110], secreted protein acidic and rich in cysteine (SPARC) [111-113]. To make progress on the characterization of the "secretome" in an unbiased manner, we implemented an initial mass spectrometrybased proteomics study to identify secreted proteins in the mouse skeletal muscle cell line C2C12 [114]. Furthermore, a more quantitative approach using stable-isotope labelling by amino acids in cell culture (SILAC) in conjunction with online reverse phase liquid chromatography tandem mass spectrometry (RPLC-MS/MS), has now been implemented to identify differentially expressed secreted proteins during myogenesis.

\section{Workflow of SILAC Quantification}

In differential proteomics, stable-isotope labelling, for example, ${ }^{2} \mathrm{H}$ versus ${ }^{1} \mathrm{H},{ }^{13} \mathrm{C}$ versus ${ }^{12} \mathrm{C}$, and ${ }^{15} \mathrm{~N}$ versus ${ }^{14} \mathrm{~N}$, is employed to introduce a signature mass difference between the samples of interest (e.g., treatment versus control). After enzymatic protein digest, the ratios of the labelled peptide peak intensities reveal the relative protein expression. There are two general ways to introduce the stable-isotope label into the sample: (1) chemical labelling, typically achieved via the isotope-coded affinity tag (ICAT) or the isobaric tag for relative and absolute quantitation (iTRAQ); (2) metabolic labelling, conveniently performed via SILAC. ICAT targets the sulfhydryl group on the cysteine residue [115], whereas iTRAQ modifies the amino group on the $\mathrm{N}$-terminus and the lysine residue [116]. For SILAC, stable-isotope labelled amino acids are metabolically incorporated into the living cells as they grow. Irrespective of the labelling methodology, the tagged samples are then combined and processed as one in subsequent treatment, separation, and analysis. This minimizes the impact of nonquantitative recovery of the proteins and peptides in these steps on the accuracy of the quantification $[117,118]$.

In recent years, SILAC has been widely applied to various biological models and cell types, including immune B cells [119], fibroblasts [120], neuronal cells [121], blood cells [122], lung cells [123], chondrocytes [124], prostate cancer [125], ovarian cancer [126], liver cancer [127, 128], breast cancer $[129,130]$, esophageal cancer $[131,132]$, and embryonic stem cells [133-135]. In addition, it has also been successfully implemented in tissues $[136,137]$ and living organisms [122, 138-140].

We employed SILAC labelling in an attempt to identify differentially expressed secreted factors at the myotube- versus myoblast-stage (i.e., differentiation versus proliferation) in $\mathrm{C} 2 \mathrm{C} 12$ cells. As illustrated in Figure 3, CM proteins derived from $\left[{ }^{12} \mathrm{C}_{6}\right]$-lysine labelled myoblasts (light) and $\left[{ }^{13} \mathrm{C}_{6}\right]$-lysine labelled myotubes (heavy) were mixed in equal amounts and subjected to one-dimensional gel electrophoresis (1D-SDS PAGE), followed by trypsin digestion. The resulting tryptic peptides were analyzed by online RPLCMS/MS. The ratio of the heavy- versus light-labelled peptide peak intensities in the MS mass spectrum mirrored the relative expression level of that particular protein during myogenesis.

\section{Implications of the Secreted Proteins Identified in Myogenesis}

As previously discussed, myogenesis is a multistep process, beginning with myogenic lineage specification, followed by cell proliferation, cell-cycle arrest, and ultimately the differentiation of myoblasts into myotubes. We postulated that each of these steps is regulated by secreted factor(s). According to our preliminary data, novel secreted proteins, such as osteoglycin (OGN), peroxiredoxin 1 (Prx1), and cytokine-induced apoptosis inhibitor 1 (CIAPIN1), were identified as differentially expressed proteins. Their respective role(s) in myogenesis were proposed as follows.

3.1. OGN. OGN is also known as mimecan. It belongs to the small leucine-rich repeat proteoglycan (SLRP) family of proteins [141-147]. This protein was found to be essential in maintaining the integrity of the extracellular matrix (ECM) of the cornea $[148,149]$ and the vascular smooth muscle $[150,151]$ by inhibiting the ECM-cleaving enzyme gelatinase [152]. This anti-ECM cleaving property contributed to OGN's tumour suppressor role in hepatocarcinoma cells by attenuating tumour cell migration [153]. Given OGN's differential expression in myogenesis, we hypothesized that OGN may play an inhibitory role by hindering myoblast migration and the subsequent cell-cell contact. As result, cellcycle arrest is inhibited and hence the muscle differentiation program is sabotaged. Interestingly, the $\mathrm{E}$ box has been identified in the promoter region of OGN [154]. This projects a compelling regulation mechanism of OGN during 


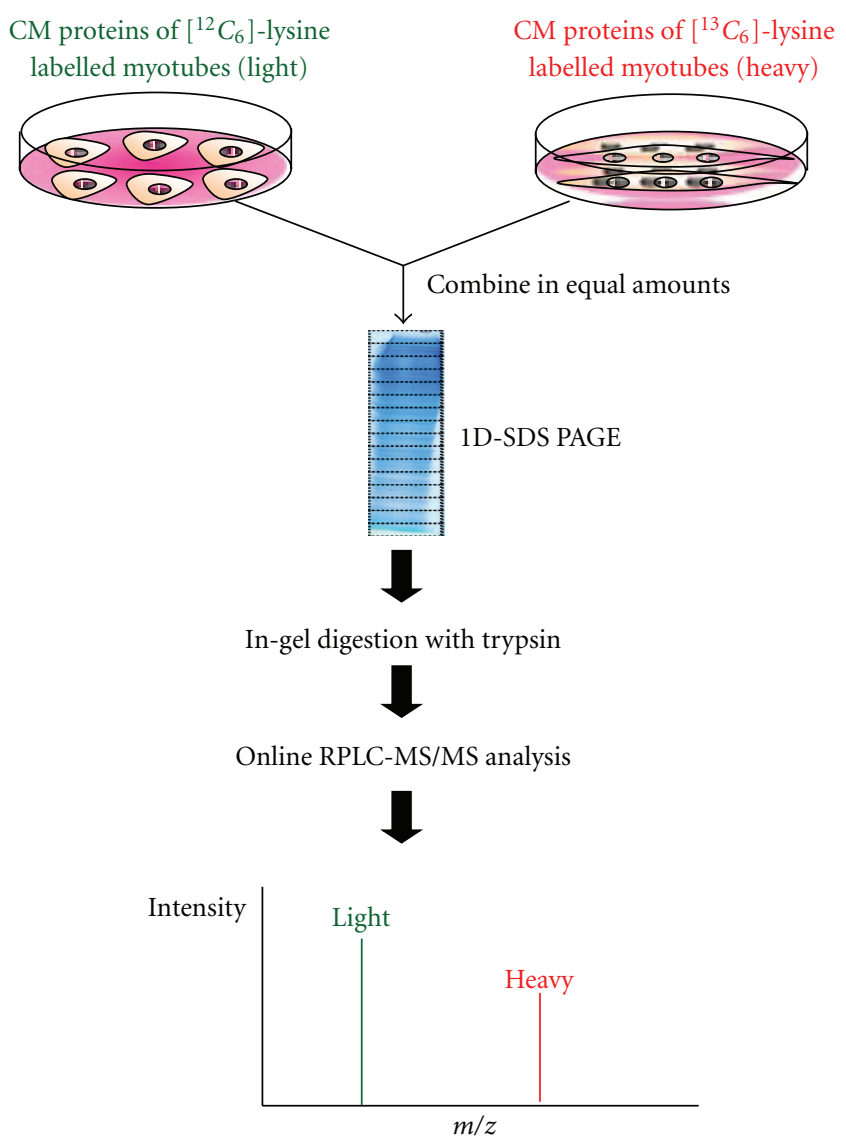

FIGURE 3: The workflow of using SILAC to identify differentially expressed secreted factors during skeletal myogenesis.

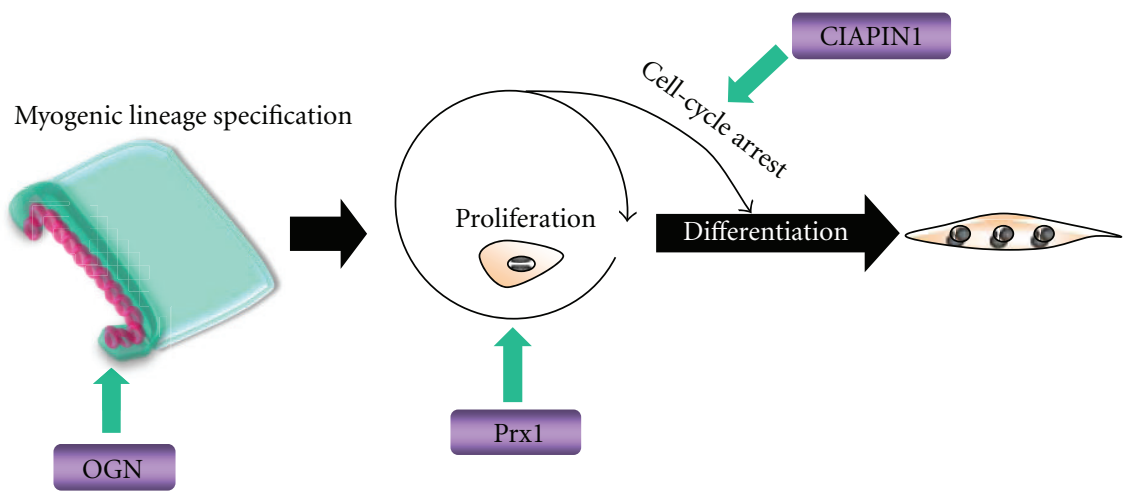

Figure 4: Overview of the implications of OGN, Prx1, and CIAPIN1 in myogenesis.

myogenesis in which binding of the MRF and $\mathrm{E}$ protein heterodimer to the $\mathrm{E}$ box may function as a docking site to recruit a chromatin remodelling molecule, such as histone deacetyltransferases (HDACs); as consequence, the transcription and subsequent expression of OGN decrease.

Furthermore, OGN may also play a role in myogenic lineage commitment, where the protein was initially identified as a bone-inductive factor [155-159]. Intriguingly, we have demonstrated the possibility that $\mathrm{C} 2 \mathrm{C} 12$ myoblasts could be recommitted to the osteoblast lineage by overexpressing a bone-inductive gene called menin 1 [160]. With this taken into account, it is tempting for us to speculate a plausible link between OGN and menin1 in which downregulation of OGN may be essential in directing the myoblasts to myogenic lineage.

3.2. Prx1. Prx1, also known as Pag [161] or MSP23 [162], belongs to the antioxidant protein family for cellular defence against reactive oxygen species (ROS) [163]. Prx1 was revealed to be upregulated in various cancer types, such as oral cancer [164], lung cancer [165-172], pancreatic cancer [173], and esophageal cancer [174]. Expression level 
of Prx1 was shown to positively correlate with cancer progression; knocking down Prx1 not only attenuated malignancy, but also sensitized the cancer cells to chemotherapy and improved survival [175-177]. Given the role of Prx1 as a prosurvival factor by blocking apoptosis signalregulating kinase (ASK)- induced cell death [178-180], we hypothesized that Prxl may function as a mitogen that promotes the proliferation of myoblasts. As proliferation and differentiation are mutually exclusive events, the downregulation of Prx1 (unpublished data) may be essential for the withdrawal of myoblasts from the proliferation cycle and subsequent differentiation.

3.3. CIAPIN1. CIAPIN1 has been characterized as an antiproliferation molecule in cell division and angiogenesis [181-183]. CIAPIN1 was shown to be a suppressor of various cancers, for instance gastric cancer [184], renal carcinoma [185], esophageal cancer [186], and colorectal cancer [187]. The antiproliferation effect of CIAPIN1 was found to be mediated by upregulating CDKI, which in turn allows $\mathrm{pRb}$ to inhibit the E2F transcription factor from activating downstream proliferation events; as a result, cellcycle arrest prevails $[185,188]$. We postulated that CIAPIN1 may function as a positive regulator of myogenesis, in which the upregulation of CIAPIN1 (unpublished data) may be essential in triggering cell-cycle arrest of myoblasts for subsequent differentiation to take place.

\section{Conclusion}

We have demonstrated the fidelity of applying SILAC to identify secreted factors during skeletal myogenesis in an unbiased proteomics approach. OGN, Prx1, and CIAPIN1 were identified as novel differentially expressed extracellular factors that are proposed to play a role in the myogenic program (Figure 4). Based on the findings of this "discovery" approach, gain and loss of function studies are now in progress to further dissect these proteins' individual and combinatorial roles in myogenesis. The identification of secretome factors that regulate myogenesis will enhance our knowledge of extracellular regulation of differentiation as well as identify biomarkers of potential therapeutic value in muscle regeneration and stem cell programming.

\section{Abbreviations}

1D-SDS PAGE: One-dimensional gel electrophoresis

ASK:

bHLH: Apoptosis signal-regulating kinase

CDKIs:

CDKs:

CDO:

CIAPIN1: $\quad$ Cytokine-induced apoptosis inhibitor 1

CM:

DML:

ECM:

HATs: HDACs:
ICAT:

IGF1:

iTRAQ:

MEF2:

MRFs:

Myf5:

MyoD:

OGN:

PCAF:

pRb:

Prx1:

ROS:

RPLC-MS/MS: Reversed phase liquid chromatography tandem mass spectrometry

SILAC: $\quad$ Stable isotope labelling by amino acids in cell culture

SLRP:

SPARC:

Small leucine-rich repeat proteoglycan

TGF:

VLL:

\section{Acknowledgments}

This work was made possible by support from the Natural Sciences and Engineering Research Council (NSERC) of Canada and from the Canadian Institutes of Health Research (CIHR) to JCM and KWMS.

\section{References}

[1] B. W. Youn and G. M. Malacinski, "A comparative analysis of amphibian somite morhphogenesis: cell rearrangement patterns during rosette formation and myoblast fusion," Journal of Embryology and Experimental Morphology, vol. 66, pp. 1-26, 1981.

[2] C. P. Ordahl and N. M. Le Douarin, "Two myogenic lineages within the developing somite," Development, vol. 114, no. 2, pp. 339-353, 1992.

[3] O. Pourquie, M. Coltey, M. A. Teillet, C. Ordahl, and N. M. Le Douarin, "Control of dorsoventral patterning of somitic derivatives by notochord and floor plate," Proceedings of the National Academy of Sciences of the United States of America, vol. 90, no. 11, pp. 5242-5246, 1993.

[4] B. Christ and C. P. Ordahl, "Early stages of chick somite development," Anatomy and Embryology, vol. 191, no. 5, pp. 381-396, 1995.

[5] N. Kato and H. Aoyama, "Dermomyotomal origin of the ribs as revealed by extirpation and transplantation experiments in chick and quail embryos," Development, vol. 125, no. 17, pp. 3437-3443, 1998.

[6] M. Buckingham, L. Bajard, T. Chang et al., "The formation of skeletal muscle: from somite to limb," Journal of Anatomy, vol. 202, no. 1, pp. 59-86, 2003.

[7] J. B. Gurdon, "A community effect in animal development," Nature, vol. 336, no. 6201, pp. 772-774, 1988.

[8] J. B. Gurdon, E. Tiller, J. Roberts, and K. Kato, "A community effect in muscle development," Current Biology, vol. 3, no. 1, pp. 1-11, 1993. 
[9] G. Cossu, R. Kelly, S. Di Donna, E. Vivarelli, and M. Buckingham, "Myoblast differentiation during mammalian somitogenesis is dependent upon a community effect," Proceedings of the National Academy of Sciences of the United States of America, vol. 92, no. 6, pp. 2254-2258, 1995.

[10] X. Graña, J. Garriga, and X. Mayol, "Role of the retinoblastoma protein family, pRB, p107 and p130 in the negative control of cell growth," Oncogene, vol. 17, no. 25, pp. 33653383, 1998.

[11] S. Tamrakar, E. Rubin, and J. W. Ludlow, "Role of pRB dephosphorylation in cell cycle regulation," Front Biosci, vol. 5, pp. D121-137, 2000.

[12] G. De Falco, F. Comes, and C. Simone, "pRb: master of differentiation. Coupling irreversible cell cycle withdrawal with induction of muscle-specific transcription," Oncogene, vol. 25, no. 38, pp. 5244-5249, 2006.

[13] K. Buchkovich, L. A. Duffy, and E. Harlow, "The retinoblastoma protein is phosphorylated during specific phases of the cell cycle," Cell, vol. 58, no. 6, pp. 1097-1105, 1989.

[14] P. L. Chen, P. Scully, J. Y. Shew, J. Y. J. Wang, and W. H. Lee, "Phosphorylation of the retinoblastoma gene product is modulated during the cell cycle and cellular differentiation," Cell, vol. 58, no. 6, pp. 1193-1198, 1989.

[15] J. A. DeCaprio, J. W. Ludlow, D. Lynch et al., "The product of the retinoblastoma susceptibility gene has properties of a cell cycle regulatory element," Cell, vol. 58, no. 6, pp. 1085-1095, 1989.

[16] J. Kato, H. Matsushime, S. W. Hiebert, M. E. Ewen, and C. J. Sherr, "Direct binding of cyclin D to the retinoblastoma gene product $(\mathrm{pRb})$ and $\mathrm{pRb}$ phosphorylation by the cyclin D-dependent kinase CDK4," Genes and Development, vol. 7, no. 3, pp. 331-342, 1993.

[17] M. N. Obeyesekere, J. R. Herbert, and S. O. Zimmerman, "A model of the G1 phase of the cell cycle incorporating cyclin $\mathrm{E} / \mathrm{cdk} 2$ complex and retinoblastoma protein," Oncogene, vol. 11, no. 6, pp. 1199-1205, 1995.

[18] J. W. Harbour, R. X. Luo, A. Dei Santi, A. A. Postigo, and D. C. Dean, "Cdk phosphorylation triggers sequential intramolecular interactions that progressively block $\mathrm{Rb}$ functions as cells move through G1," Cell, vol. 98, no. 6, pp. 859-869, 1999.

[19] B. Ren, H. Cam, Y. Takahashi et al., "E2F integrates cell cycle progression with DNA repair, replication, and G2/M checkpoints," Genes and Development, vol. 16, no. 2, pp. 245256, 2002.

[20] R. L. Davis, H. Weintraub, and A. B. Lassar, "Expression of a single transfected cDNA converts fibroblasts to myoblasts," Cell, vol. 51, no. 6, pp. 987-1000, 1987.

[21] J. Choi, M. L. Costa, C. S. Mermelstein, C. Chagas, S. Holtzer, and H. Holtzer, "MyoD converts primary dermal fibroblasts, chondroblasts, smooth muscle, and retinal pigmented epithelial cells into striated mononucleated myoblasts and multinucleated myotubes," Proceedings of the National Academy of Sciences of the United States of America, vol. 87, no. 20, pp. 7988-7992, 1990.

[22] T. Braun, G. Buschhausen-Denker, E. Bober, E. Tannich, and H. H. Arnold, "A novel human muscle factor related to but distinct from MyoD1 induces myogenic conversion in 10T1/2 fibroblasts," The EMBO Journal, vol. 8, no. 3, pp. 701-709, 1989.

[23] S. Tajbakhsh, D. Rocancourt, and M. Buckingham, "Muscle progenitor cells failing to respond to positional cues adopt non-myogenic fates in myf-5 null mice," Nature, vol. 384, no. 6606, pp. 266-270, 1996.
[24] R. Benezra, R. L. Davis, D. Lockshon, D. L. Turner, and H. Weintraub, "The protein Id: a negative regulator of helixloop-helix DNA binding proteins," Cell, vol. 61, no. 1, pp. 49-59, 1990.

[25] L. A. Neuhold and B. Wold, "HLH forced dimers: tethering MyoD to E47 generates a dominant positive myogenic factor insulated from negative regulation by Id," Cell, vol. 74, no. 6, pp. 1033-1042, 1993.

[26] M. Hebrok, K. Wertz, and E. M. Fuchtbauer, "M-twist is an inhibitor of muscle differentiation," Developmental Biology, vol. 165, no. 2, pp. 537-544, 1994.

[27] D. B. Spicer, J. Rhee, W. L. Cheung, and A. B. Lassar, "Inhibition of myogenic bHLH and MEF2 transcription factors by the bHLH protein twist," Science, vol. 272, no. 5267, pp. 1476-1480, 1996.

[28] Y. Hamamori, H. Y. Wu, V. Sartorelli, and L. Kedes, "The basic domain of myogenic basic helix-loop-helix (bHLH) proteins is the novel target for direct inhibition by another bHLH protein, twist," Molecular and Cellular Biology, vol. 17, no. 11, pp. 6563-6573, 1997.

[29] J. Lu, R. Webb, J. A. Richardson, and E. N. Olson, "MyoR: a muscle-restricted basic helix-loop-helix transcription factor that antagonizes the actions of MyoD," Proceedings of the National Academy of Sciences of the United States of America, vol. 96, no. 2, pp. 552-557, 1999.

[30] L. Yu, N. Sangster, A. Perez, and P. J. McCormick, "The bHLH protein MyoR inhibits the differentiation of early embryonic endoderm," Differentiation, vol. 72, no. 7, pp. 341-347, 2004.

[31] C. Lemercier, R. Q. To, R. A. Carrasco, and S. F. Konieczny, "The basic helix-loop-helix transcription factor Mistl functions as a transcriptional repressor of MyoD," The EMBO Journal, vol. 17, no. 5, pp. 1412-1422, 1998.

[32] C. M. A. Chen, N. Kraut, M. Groudine, and H. Weintraub, "I-mf, a novel myogenic repressor, interacts with members of the MyoD family," Cell, vol. 86, no. 5, pp. 731-741, 1996.

[33] A. B. Lassar, R. L. Davis, W. E. Wright et al., "Functional activity of myogenic HLH proteins requires heterooligomerization with E12/E47-like proteins in vivo," Cell, vol. 66, no. 2, pp. 305-315, 1991.

[34] A. N. Song, Q. I. Wang, M. G. Goebl, and M. A. Harrington, "Phosphorylation of nuclear MyoD is required for its rapid degradation," Molecular and Cellular Biology, vol. 18, no. 9, pp. 4994-4999, 1998.

[35] M. Kitzmann, M. Vandromme, V. Schaeffer et al., "cdk1and cdk2-mediated phosphorylation of MyoD Ser200 in growing C2 myoblasts: role in modulating MyoD half-life and myogenic activity," Molecular and Cellular Biology, vol. 19, no. 4, pp. 3167-3176, 1999.

[36] Z. E. Floyd, J. S. Trausch-Azar, E. Reinstein, A. Ciechanover, and A. L. Schwartz, "The nuclear ubiquitin-proteasome system degrades MyoD," Journal of Biological Chemistry, vol. 276, no. 25, pp. 22468-22475, 2001.

[37] K. Hatta, S. Takagi, H. Fujisawa, and M. Takeichi, "Spatial and temporal expression pattern of $\mathrm{N}$-cadherin cell adhesion molecules correlated with morphogenetic processes of chicken embryos," Developmental Biology, vol. 120, no. 1, pp. 215-227, 1987.

[38] K. A. Knudsen, L. Myers, and S. A. McElwee, "A role for the $\mathrm{Ca}^{2+}$-dependent adhesion molecular, N-cadherin, in myoblast interaction during myogenesis," Experimental Cell Research, vol. 188, no. 2, pp. 175-184, 1990.

[39] C. E. Holt, P. Lemaire, and J. B. Gurdon, "Cadherin-mediated cell interactions are necessary for the activation of MyoD in 
Xenopus mesoderm," Proceedings of the National Academy of Sciences of the United States of America, vol. 91, no. 23, pp. 10844-10848, 1994.

[40] M. Zeschnigk, D. Kozian, C. Kuch, M. Schmoll, and A. Starzinski-Powitz, "Involvement of M-cadherin in terminal differentiation of skeletal muscle cells," Journal of Cell Science, vol. 108, no. 9, pp. 2973-2981, 1995.

[41] M. George-Weinstein, J. Gerhart, J. Blitz, E. Simak, and K. A. Knudsen, "N-cadherin promotes the commitment and differentiation of skeletal muscle precursor cells," Developmental Biology, vol. 185, no. 1, pp. 14-24, 1997.

[42] P. Goichberg and B. Geiger, "Direct involvement of Ncadherin-mediated signaling in muscle differentiation," Molecular Biology of the Cell, vol. 9, no. 11, pp. 3119-3131, 1998.

[43] J. Gavard, V. Marthiens, C. Monnet, M. Lambert, and R. M. Mège, "N-cadherin activation substitutes for the cell contact control in cell cycle arrest and myogenic differentiation: involvement of p120 and $\beta$-catenin," Journal of Biological Chemistry, vol. 279, no. 35, pp. 36795-36802, 2004.

[44] G. Messina, C. Blasi, S. A. La Rocca, M. Pompili, A. Calconi, and M. Grossi, "p27 acts downstream of N-cadherinmediated cell adhesion to promote myogenesis beyond cell cycle regulation," Molecular Biology of the Cell, vol. 16, no. 3, pp. 1469-1480, 2005.

[45] E. G. Reynaud, M. P. Leibovitch, L. A. J. Tintignac, K. Pelpel, M. Guillier, and S. A. Leibovitch, "Stabilization of MyoD by direct binding to $557^{\text {Kip2 }}$," Journal of Biological Chemistry, vol. 275, no. 25, pp. 18767-18776, 2000.

[46] L. A. J. Tintignac, V. Sirri, M. P. Leibovitch et al., "Mutant MyoD lacking Cdc2 phosphorylation sites delays M-phase entry," Molecular and Cellular Biology, vol. 24, no. 4, pp. 1809-1821, 2004.

[47] E. K. Flemington, S. H. Speck, and W. G. Kaelin, "E2F-1mediated transactivation is inhibited by complex formation with the retinoblastoma susceptibility gene product," Proceedings of the National Academy of Sciences of the United States of America, vol. 90, no. 15, pp. 6914-6918, 1993.

[48] M. V. Frolov and N. J. Dyson, "Molecular mechanisms of E2F-dependent activation and pRB-mediated repression," Journal of Cell Science, vol. 117, no. 11, pp. 2173-2181, 2004.

[49] L. A. Gossett, D. J. Kelvin, E. A. Sternberg, and E. N. Olson, "A new myocyte-specific enhancer-binding factor that recognizes a conserved element associated with multiple muscle-specific genes," Molecular and Cellular Biology, vol. 9, no. 11, pp. 5022-5033, 1989.

[50] Y. T. Yu, R. E. Breitbart, L. B. Smoot, Y. Lee, V. Mahdavi, and B. Nadal-Ginard, "Human myocyte-specific enhancer factor 2 comprises a group of tissue-restricted MADS box transcription factors," Genes and Development, vol. 6, no. 9, pp. 1783-1798, 1992.

[51] J. D. Molkentin, B. L. Black, J. F. Martin, and E. N. Olson, "Cooperative activation of muscle gene expression by MEF2 and myogenic bHLH proteins," Cell, vol. 83, no. 7, pp. 11251136, 1995.

[52] J. D. Molkentin and E. N. Olson, "Combinatorial control of muscle development by basic helix-loop-helix and MADS-box transcription factors," Proceedings of the National Academy of Sciences of the United States of America, vol. 93, no. 18, pp. 9366-9373, 1996.

[53] J. E. Brownell and C. D. Allis, "Special HATs for special occasions: linking histone acetylation to chromatin assembly and gene activation," Current Opinion in Genetics and Development, vol. 6, no. 2, pp. 176-184, 1996.
[54] W. Yuan, G. Condorelli, M. Caruso, A. Felsani, and A. Giordanoi, "Human p300 protein is a coactivator for the transcription factor MyoD," Journal of Biological Chemistry, vol. 271, no. 15, pp. 9009-9013, 1996.

[55] P. L. Puri, V. Sartorelli, X. J. Yang et al., "Differential roles of p300 and PCAF acetyltransferases in muscle differentiation," Molecular Cell, vol. 1, no. 1, pp. 35-45, 1997.

[56] P. L. Puri, M. L. Avantaggiati, C. Balsano et al., "p300 is required for MyoD-dependent cell cycle arrest and musclespecific gene transcription," The EMBO Journal, vol. 16, no. 2, pp. 369-383, 1997.

[57] V. Sartorelli, J. Huang, Y. Hamamori, and L. Kedes, "Molecular mechanisms of myogenic coactivation by p300: direct interaction with the activation domain of $\mathrm{MyoD}$ and with the MADS box of MEF2C," Molecular and Cellular Biology, vol. 17, no. 2, pp. 1010-1026, 1997.

[58] V. Sartorelli, P. L. Puri, Y. Hamamori et al., "Acetylation of MyoD directed by PCAF is necessary for the execution of the muscle program," Molecular Cell, vol. 4, no. 5, pp. 725-734, 1999.

[59] A. Polesskaya, A. Duquet, I. Naguibneva et al., "CREBbinding protein/p300 activates MyoD by acetylation," Journal of Biological Chemistry, vol. 275, no. 44, pp. 34359-34364, 2000.

[60] A. Polesskaya, I. Naguibneva, L. Fritsch et al., "CBP/p300 and muscle differentiation: no HAT, no muscle," The EMBO Journal, vol. 20, no. 23, pp. 6816-6825, 2001.

[61] A. Polesskaya, I. Naguibneva, A. Duquet, E. Bengal, P. Robin, and A. Harel-Bellan, "Interaction between acetylated MyoD and the bromodomain of CBP and/or p300," Molecular and Cellular Biology, vol. 21, no. 16, pp. 5312-5320, 2001.

[62] F. J. Dilworth, K. J. Seaver, A. L. Fishburn, S. L. Htet, and S. J. Tapscott, "In vitro transcription system delineates the distinct roles of the coactivators pCAF and p300 during MyoD/E47-dependent transactivation," Proceedings of the National Academy of Sciences of the United States of America, vol. 101, no. 32, pp. 11593-11598, 2004.

[63] J. S. Kang, M. Gao, J. L. Feinleib, P. D. Cotter, S. N. Guadagno, and R. S. Krauss, "CDO: an oncogene-, serum-, and anchorage-regulated member of the Ig/fibronectin type III repeat family," Journal of Cell Biology, vol. 138, no. 1, pp. 203-213, 1997.

[64] J. S. Kang, P. J. Mulieri, C. Miller, D. A. Sassoon, and R. S. Krauss, "CDO, a Robo-related cell surface protein that mediates myogenic differentiation," Journal of Cell Biology, vol. 143, no. 2, pp. 403-413, 1998.

[65] G. Takaesu, J. S. Kang, G. U. Bae et al., "Activation of $\mathrm{p} 38 \alpha / \beta$ MAPK in myogenesis via binding of the scaffold protein JLP to the cell surface protein Cdo," Journal of Cell Biology, vol. 175, no. 3, pp. 383-388, 2006.

[66] J. S. Kang, G. U. Bae, M. J. Yi et al., "A Cdo-Bnip-2Cdc42 signaling pathway regulates $\mathrm{p} 38 \alpha / \beta$ MAPK activity and myogenic differentiation," Journal of Cell Biology, vol. 182, no. 3, pp. 497-507, 2008.

[67] G. U. Bae, B. G. Kim, H. J. Lee et al., "Cdo binds Abl to promote $\mathrm{p} 38 \alpha / \beta$ mitogen-activated protein kinase activity and myogenic differentiation," Molecular and Cellular Biology, vol. 29, no. 15, pp. 4130-4143, 2009.

[68] M. Lu and R. S. Krauss, "N-cadherin ligation, but not Sonic hedgehog binding, initiates Cdo-dependent p38 $\alpha / \beta$ MAPK signaling in skeletal myoblasts," Proceedings of the National Academy of Sciences of the United States of America, vol. 107, no. 9, pp. 4212-4217, 2010. 
[69] A. Cuenda and P. Cohen, "Stress-activated protein kinase$2 /$ p38 and a rapamycin-sensitive pathway are required for C2C12 myogenesis," Journal of Biological Chemistry, vol. 274, no. 7, pp. 4341-4346, 1999.

[70] F. Lluís, E. Perdiguero, A. R. Nebreda, and P. MuñozCánoves, "Regulation of skeletal muscle gene expression by p38 MAP kinases," Trends in Cell Biology, vol. 16, no. 1, pp. 36-44, 2006.

[71] E. Perdiguero, V. Ruiz-Bonilla, L. Gresh et al., "Genetic analysis of p38 MAP kinases in myogenesis: fundamental role of p38 $\alpha$ in abrogating myoblast proliferation," The EMBO Journal, vol. 26, no. 5, pp. 1245-1256, 2007.

[72] A. Zetser, E. Gredinger, and E. Bengal, "p38 mitogenactivated protein kinase pathway promotes skeletal muscle differentiation: participation of the MEF2C transcription factor," Journal of Biological Chemistry, vol. 274, no. 8, pp. 5193-5200, 1999.

[73] Z. Wu, P. J. Woodring, K. S. Bhakta et al., "p38 and extracellular signal-regulated kinases regulate the myogenic program at multiple steps," Molecular and Cellular Biology, vol. 20, no. 11, pp. 3951-3964, 2000.

[74] F. Lluís, E. Ballestar, M. Suelves, M. Esteller, and P. MuñozCánoves, "E47 phosphorylation by p38 MAPK promotes MyoD/E47 association and muscle-specific gene transcription," The EMBO Journal, vol. 24, no. 5, pp. 974-984, 2005.

[75] C. Simone, S. V. Forcales, D. A. Hill, A. N. Imbalzano, L. Latella, and P. L. Puri, "p38 pathway targets SWISNF chromatin-remodeling complex to muscle-specific loci," Nature Genetics, vol. 36, no. 7, pp. 738-743, 2004.

[76] F. Cole, W. Zhang, A. Geyra, J. S. Kang, and R. S. Krauss, "Positive regulation of myogenic bHLH factors and skeletal muscle development by the cell surface receptor CDO," Developmental Cell, vol. 7, no. 6, pp. 843-854, 2004.

[77] R. Bischoff, "A satellite cell mitogen from crushed adult muscle," Developmental Biology, vol. 115, no. 1, pp. 140-147, 1986.

[78] R. Bischoff, "Interaction between satellite cells and skeletal muscle fibers," Development, vol. 109, no. 4, pp. 943-952, 1990.

[79] D. Engler, "Hypothesis: musculin is a hormone secreted by skeletal muscle, the body's largest endocrine organ. Evidence for actions on the endocrine pancreas to restrain the beta-cell mass and to inhibit insulin secretion and on the hypothalamus to co-ordinate the neuroendocrine and appetite responses to exercise," Acta Bio-Medica: Atenei Parmensis, vol. 78, supplement 1, pp. 156-206, 2007.

[80] B. K. Pedersen and M. A. Febbraio, "Muscle as an endocrine organ: focus on muscle-derived interleukin-6," Physiological Reviews, vol. 88, no. 4, pp. 1379-1406, 2008.

[81] J. R. Florini, D. Z. Ewton, K. A. Magri, and F. J. Mangiacapra, "IGFs and muscle differentiation," Advances in Experimental Medicine and Biology, vol. 343, pp. 319-326, 1993.

[82] J. P. Liu, J. Baker, A. S. Perkins, E. J. Robertson, and A. Efstratiadis, "Mice carrying null mutations of the genes encoding insulin-like growth factor I (Igf-1) and type 1 IGF receptor (Igf1r)," Cell, vol. 75, no. 1, pp. 59-72, 1993.

[83] L. Powell-Braxton, P. Hollingshead, C. Warburton et al., "IGF-I is required for normal embryonic growth in mice," Genes and Development, vol. 7, no. 12 B, pp. 2609-2617, 1993.

[84] M. E. Coleman, F. DeMayo, K. C. Yin et al., "Myogenic vector expression of insulin-like growth factor I stimulates muscle cell differentiation and myofiber hypertrophy in transgenic mice," Journal of Biological Chemistry, vol. 270, no. 20, pp. 12109-12116, 1995.
[85] E. R. Barton-Davis, D. I. Shoturma, A. Musaro, N. Rosenthal, and H. Lee Sweeney, "Viral mediated expression of insulinlike growth factor I blocks the aging-related loss of skeletal muscle function," Proceedings of the National Academy of Sciences of the United States of America, vol. 95, no. 26, pp. 15603-15607, 1998.

[86] M. A. Lawlor and P. Rotwein, "Coordinate control of muscle cell survival by distinct insulin-like growth factor activated signaling pathways," Journal of Cell Biology, vol. 151, no. 6, pp. 1131-1140, 2000.

[87] M. A. Lawlor and P. Rotwein, "Insulin-like growth factormediated muscle cell survival: central roles for Akt and cyclin-dependent kinase inhibitor p21," Molecular and Cellular Biology, vol. 20, no. 23, pp. 8983-8995, 2000.

[88] M. A. Lawlor, X. Feng, D. R. Everding, K. Sieger, C. E. H. Stewart, and P. Rotwein, "Dual control of muscle cell survival by distinct growth factor-regulated signaling pathways," Molecular and Cellular Biology, vol. 20, no. 9, pp. 3256-3265, 2000.

[89] E. R. Barton, L. Morris, A. Musaro, N. Rosenthal, and H. L. Sweeney, "Muscle-specific expression of insulin-like growth factor I counters muscle decline in mdx mice," Journal of Cell Biology, vol. 157, no. 1, pp. 137-147, 2002.

[90] A. Musaró, C. Giacinti, G. Borsellino et al., "Stem cellmediated muscle regeneration is enhanced by local isoform of insulin-like growth factor 1," Proceedings of the National Academy of Sciences of the United States of America, vol. 101, no. 5, pp. 1206-1210, 2004.

[91] J. R. Florini, A. B. Roberts, and D. Z. Ewton, “Transforming growth factor- $\beta$. A very potent inhibitor of myoblast differentiation, identical to the differentiation inhibitor secreted by Buffalo rat liver cells," Journal of Biological Chemistry, vol. 261, no. 35, pp. 16509-16513, 1986.

[92] J. Massague, S. Cheifetz, T. Endo, and B. Nadal-Ginard, “Type $\beta$ transforming growth factor is an inhibitor of myogenic differentiation," Proceedings of the National Academy of Sciences of the United States of America, vol. 83, no. 21, pp. 8206-8210, 1986.

[93] E. N. Olson, E. Sternberg, and J. S. Hu, "Regulation of myogenic differentiation by type $\beta$ transforming growth factor," Journal of Cell Biology, vol. 103, no. 5, pp. 1799-1805, 1986.

[94] T. J. Brennan, D. G. Edmondson, L. Li, and E. N. Olson, "Transforming growth factor $\beta$ represses the actions of myogenin through a mechanism independent of DNA binding," Proceedings of the National Academy of Sciences of the United States of America, vol. 88, no. 9, pp. 3822-3826, 1991.

[95] J. F. Martin, L. Li, and E. N. Olson, "Repression of myogenin function by TGF- $\beta 1$ is targeted at the basic helix-loophelix motif and is independent of E2A products," Journal of Biological Chemistry, vol. 267, no. 16, pp. 10956-10960, 1992.

[96] L. De Angelis, S. Borghi, R. Melchionna et al., "Inhibition of myogenesis by transforming growth factor $\beta$ is densitydependent and related to the translocation of transcription factor MEF2 to the cytoplasm," Proceedings of the National Academy of Sciences of the United States of America, vol. 95, no. 21, pp. 12358-12363, 1998.

[97] D. Liu, B. L. Black, and R. Derynck, "TGF- $\beta$ inhibits muscle differentiation through functional repression of myogenic transcription factors by Smad3," Genes and Development, vol. 15, no. 22, pp. 2950-2966, 2001.

[98] D. Liu, J. S. Kang, and R. Derynck, “TGF- $\beta$-activated Smad3 represses MEF2-dependent transcription in myogenic 
differentiation," The EMBO Journal, vol. 23, no. 7, pp. 15571566, 2004.

[99] R. D. Cohn, C. Van Erp, J. P. Habashi et al., "Angiotensin II type 1 receptor blockade attenuates TGF- $\beta$-induced failure of muscle regeneration in multiple myopathic states," Nature Medicine, vol. 13, no. 2, pp. 204-210, 2007.

[100] B. W. Festoff, M. R. Patterson, and K. Romstedt, "Plasminogen activator: the major secreted neutral protease of cultured skeletal muscle cells," Journal of Cellular Physiology, vol. 110, no. 2, pp. 190-195, 1982.

[101] R. L. Beach, J. S. Rao, and B. W. Festoff, "Extracellular-matrix synthesis by skeletal muscle in culture. Major secreted collagenous protein of clonal myoblasts," Biochemical Journal, vol. 225, no. 3, pp. 619-627, 1985.

[102] E. Brandan, M. E. Fuentes, and W. Andrade, "The proteoglycan decorin is synthesized and secreted by differentiated myotubes," European Journal of Cell Biology, vol. 55, no. 2, pp. 209-216, 1991.

[103] J. R. Florini, D. S. Samuel, D. Z. Ewton, C. Kirk, and R. M. Sklar, "Stimulation of myogenic differentiation by a neuregulin, glial growth factor 2: are neuregulins the longsought muscle trophic factors secreted by nerves?" Journal of Biological Chemistry, vol. 271, no. 22, pp. 12699-12702, 1996.

[104] H. Nishimune, A. Uyeda, M. Nogawa, K. Fujimori, and T. Taguchi, "Neurocrescin: a novel neurite-outgrowth factor secreted by muscle after denervation," NeuroReport, vol. 8, no. 16, pp. 3649-3654, 1997.

[105] B. J. Gilpin, F. Loechel, M. G. Mattei, E. Engvall, R. Albrechtsen, and U. M. Wewer, "A novel secreted form of human ADAM 12 (meltrin $\alpha$ ) provokes myogenesis in vivo," Journal of Biological Chemistry, vol. 273, no. 1, pp. 157-166, 1998.

[106] H. Nishizawa, M. Matsuda, Y. Yamada et al., "Musclin, a novel skeletal muscle-derived secretory factor," Journal of Biological Chemistry, vol. 279, no. 19, pp. 19391-19395, 2004.

[107] K. Tateno, T. Minamino, H. Toko et al., "Critical roles of muscle-secreted angiogenic factors in therapeutic neovascularization," Circulation Research, vol. 98, no. 9, pp. 11941202, 2006.

[108] F. Haugen, F. Norheim, H. Lian et al., "IL-7 is expressed and secreted by human skeletal muscle cells," American Journal of Physiology, vol. 298, no. 4, pp. C807-C816, 2010.

[109] B. H. Koo, C. L. Goff, K. A. Jungers et al., "ADAMTS-like 2 (ADAMTSL2) is a secreted glycoprotein that is widely expressed during mouse embryogenesis and is regulated during skeletal myogenesis," Matrix Biology, vol. 26, no. 6, pp. 431-441, 2007.

[110] N. Ouchi, Y. Oshima, K. Ohashi et al., "Follistatin-like 1, a secreted muscle protein, promotes endothelial cell function and revascularization in ischemic tissue through a nitricoxide synthase-dependent mechanism," Journal of Biological Chemistry, vol. 283, no. 47, pp. 32802-32811, 2008.

[111] J. A. Bassuk, M. L. Iruela-Arispe, T. F. Lane, J. M. Benson, R. A. Berg, and E. H. Sage, "Molecular analysis of chicken embryo SPARC (osteonectin)," European Journal of Biochemistry, vol. 218, no. 1, pp. 117-127, 1993.

[112] W. J. Cho, E. J. Kim, S. J. Lee, H. D. Kim, H. J. Shin, and W. K. Lim, "Involvement of SPARC in in vitro differentiation of skeletal myoblasts," Biochemical and Biophysical Research Communications, vol. 271, no. 3, pp. 630-634, 2000.

[113] L. H. Jørgensen, S. J. Petersson, J. Sellathurai et al., "Secreted protein acidic and rich in cysteine (SPARC) in human skeletal muscle," Journal of Histochemistry and Cytochemistry, vol. 57, no. 1, pp. 29-39, 2009.
[114] X. C. Y. Chan, J. C. McDermott, and K. W. M. Siu, "Identification of secreted proteins during skeletal muscle development," Journal of Proteome Research, vol. 6, no. 2, pp. 698-710, 2007.

[115] S. P. Gygi, B. Rist, S. A. Gerber, F. Turecek, M. H. Gelb, and R. Aebersold, "Quantitative analysis of complex protein mixtures using isotope-coded affinity tags," Nature Biotechnology, vol. 17, no. 10, pp. 994-999, 1999.

[116] P. L. Ross, Y. N. Huang, J. N. Marchese et al., "Multiplexed protein quantitation in Saccharomyces cerevisiae using amine-reactive isobaric tagging reagents," Molecular \& Cellular Proteomics, vol. 3, no. 12, pp. 1154-1169, 2004.

[117] S. E. Ong, B. Blagoev, I. Kratchmarova et al., "Stable isotope labeling by amino acids in cell culture, SILAC, as a simple and accurate approach to expression proteomics," Molecular \& Cellular Proteomics, vol. 1, no. 5, pp. 376-386, 2002.

[118] S. E. Ong and M. Mann, "Mass spectrometry-based proteomics turns quantitative," Nature chemical biology, vol. 1, no. 5, pp. 252-262, 2005.

[119] E. P. Romijn, C. Christis, M. Wieffer et al., "Expression clustering reveals detailed co-expression patterns of functionally related proteins during $\mathrm{B}$ cell differentiation: $\mathrm{a}$ proteomic study using a combination of one-dimensional gel electrophoresis, LC-MS/MS, and stable isotope labeling by amino acids in cell culture (SILAC)," Molecular \& Cellular Proteomics, vol. 4, no. 9, pp. 1297-1310, 2005.

[120] A. F. M. Pinto, L. Ma, B. Dragulev, J. A. Guimaraes, and J. W. Fox, "Use of SILAC for exploring sheddase and matrix degradation of fibroblasts in culture by the PIII SVMP atrolysin A: identification of two novel substrates with functional relevance," Archives of Biochemistry and Biophysics, vol. 465, no. 1, pp. 11-15, 2007.

[121] A. Klegeris, J. Li, T. K. Bammler et al., "Prolyl endopeptidase is revealed following SILAC analysis to be a novel mediator of human microglial and THP-1 cell neurotoxicity," GLIA, vol. 56, no. 6, pp. 675-685, 2008.

[122] M. Krüger, M. Moser, S. Ussar et al., "SILAC mouse for quantitative proteomics uncovers kindlin-3 as an essential factor for red blood cell function," Cell, vol. 134, no. 2, pp. 353-364, 2008.

[123] X. Duan, S. G. Kelsen, A. B. Clarkson, R. Ji, and S. Merali, "SILAC analysis of oxidative stress-mediated proteins in human pneumocytes: new role for treacle," Proteomics, vol. 10, no. 11, pp. 2165-2174, 2010.

[124] M. Polacek, J.-A. Bruun, O. Johansen, and I. Martinez, "Differences in the secretome of cartilage explants and cultured chondrocytes unveiled by SILAC technology," Journal of Orthopaedic Research, vol. 28, no. 8, pp. 1040-1049, 2010.

[125] P. A. Everley, J. Krijgsveld, B. R. Zetter, and S. P. Gygi, "Quantitative cancer proteomics: stable isotope labeling with amino acids in cell culture (SILAC) as a tool for prostate cancer research," Molecular \& Cellular Proteomics, vol. 3, no. 7, pp. 729-735, 2004.

[126] R. Amanchy, D. E. Kalume, A. Iwahori, J. Zhong, and A. Pandey, "Phosphoproteome analysis of HeLa cells using stable isotope labeling with amino acids in cell culture (SILAC)," Journal of Proteome Research, vol. 4, no. 5, pp. 1661-1671, 2005.

[127] N. Chen, W. Sun, X. Deng et al., "Quantitative proteome analysis of HCC cell lines with different metastatic potentials by SILAC," Proteomics, vol. 8, no. 23-24, pp. 5108-5118, 2008. 
[128] G. Zhang, D. Fenyo, and T. A. Neubert, "Screening for EphB signaling effectors using SILAC with a linear ion traporbitrap mass spectrometer," Journal of Proteome Research, vol. 7, no. 11, pp. 4715-4726, 2008.

[129] A. Cuomo, S. Moretti, S. Minucci, and T. Bonaldi, "SILACbased proteomic analysis to dissect the "histone modification signature" of human breast cancer cells," Amino Acids, http://www.ncbi.nlm.nih.gov/pubmed/20617350. In press.

[130] Q. Zhou, R. Chaerkady, P. G. Shaw, T. W. Kensler, A. Pandey, and N. E. Davidson, "Screening for therapeutic targets of vorinostat by SILAC-based proteomic analysis in human breast cancer cells," Proteomics, vol. 10, no. 5, pp. 1029-1039, 2010.

[131] M. K. Kashyap, H. C. Harsha, S. Renuse et al., "SILACbased quantitative proteomic approach to identify potential biomarkers from the esophageal squamous cell carcinoma secretome," Cancer Biology and Therapy, vol. 10, no. 8, pp. 796-810, 2010.

[132] K. K. Lee, K. Todorova, and A. Mandinova, "Maximizing early detection of esophageal squamous cell carcinoma via SILAC-proteomics," Cancer Biology and Therapy, vol. 10, no. 8, pp. 811-813, 2010.

[133] T. A. Prokhorova, K. T. G. Rigbolt, P. T. Johansen et al., "Stable isotope labeling by amino acids in cell culture (SILAC) and quantitative comparison of the membrane proteomes of self-renewing and differentiating human embryonic stem cells," Molecular \& Cellular Proteomics, vol. 8, no. 5, pp. 959970, 2009.

[134] T. S. Collier, P. Sarkar, B. Rao, and D. C. Muddiman, "Quantitative top-down proteomics of SILAC labeled human embryonic stem cells," Journal of the American Society for Mass Spectrometry, vol. 21, no. 6, pp. 879-889, 2010.

[135] R. Tian, S. Wang, F. Elisma et al., "Rare cell proteomic reactor applied to SILAC based quantitative proteomic study of human embryonic stem cell differentiation," Molecular \& Cellular Proteomics, vol. 10, no. 2, 2011.

[136] Y. Xu, S. Liang, G. Shen et al., "Application of the SILAC (stable isotope labelling with amino acids in cell culture) technique in quantitative comparisons for tissue proteome expression," Biotechnology and Applied Biochemistry, vol. 54, no. 1, pp. 11-20, 2009.

[137] T. Geiger, J. Cox, P. Ostasiewicz, J. R. Wisniewski, and M. Mann, "Super-SILAC mix for quantitative proteomics of human tumor tissue," Nature Methods, vol. 7, no. 5, pp. 383385,2010 .

[138] J. Graumann, N. C. Hubner, J. B. Kim et al., "Stable isotope labeling by amino acids in cell culture (SILAC) and proteome quantitation of mouse embryonic stem cells to a depth of 5,111 proteins," Molecular \& Cellular Proteomics, vol. 7, no. 4, pp. 672-683, 2008.

[139] A. Cuomo and T. Bonaldi, "Systems biology "on-the-fly": SILAC-based quantitative proteomics and RNAi approach in Drosophila melanogaster," Methods in Molecular Biology, vol. 662, pp. 59-78, 2010.

[140] M. D. Sury, J.-X. Chen, and M. Selbach, "The SILAC fly allows for accurate protein quantification in vivo," Molecular \& Cellular Proteomics, vol. 9, no. 10, pp. 2173-2183, 2010.

[141] J. L. Funderburgh, L. M. Corpuz, M. R. Roth, M. L. Funderburgh, E. S. Tasheva, and G. W. Conrad, "Mimecan, the $25-\mathrm{kDa}$ corneal keratan sulfate proteoglycan, is a product of the gene producing osteoglycin," Journal of Biological Chemistry, vol. 272, no. 44, pp. 28089-28095, 1997.
[142] A. M. Hocking, T. Shinomura, and D. J. McQuillan, "Leucine-rich repeat glycoproteins of the extracellular matrix," Matrix Biology, vol. 17, no. 1, pp. 1-19, 1998.

[143] R. V. Iozzo, "Matrix proteoglycans: from molecular design to cellular function," Annual Review of Biochemistry, vol. 67, pp. 609-652, 1998.

[144] R. V. Iozzo, "The biology of the small leucine-rich proteoglycans. Functional network of interactive proteins," Journal of Biological Chemistry, vol. 274, no. 27, pp. 18843-18846, 1999.

[145] N. Matsushima, T. Ohyanagi, T. Tanaka, and R. H. Kretsinger, "Super-motifs and evolution of tandem leucine-rich repeats within the small proteoglycans-biglycan, decorin, lumican, fibromodulin, PRELP, keratocan, osteoadherin, epiphycan, and osteoglycin," Proteins: Structure, Function and Genetics, vol. 38, no. 2, pp. 210-225, 2000.

[146] S. P. Henry, M. Takanosu, T. C. Boyd et al., "Expression pattern and gene characterization of asporin. A newly discovered member of the leucine-rich repeat protein family," Journal of Biological Chemistry, vol. 276, no. 15, pp. 1221212221, 2001.

[147] P. Lorenzo, A. Aspberg, P. Önnerfjord, M. T. Bayliss, P. J. Neame, and D. Heinegård, "Identification and characterization of asporin. A novel member of the leucine-rich repeat protein family closely related to decorin and biglycan," Journal of Biological Chemistry, vol. 276, no. 15, pp. 1220112211, 2001.

[148] E. S. Tasheva, A. Koester, A. Q. Paulsen et al., "Mimecan/ osteoglycin-deficient mice have collagen fibril abnormalities," Molecular Vision, vol. 8, pp. 407-415, 2002.

[149] G. Ge, N. S. Seo, X. Liang, D. R. Hopkins, M. Höök, and D. S. Greenspan, "Bone morphogenetic protein-1/tolloidrelated metalloproteinases process osteoglycin and enhance its ability to regulate collagen fibrillogenesis," Journal of Biological Chemistry, vol. 279, no. 40, pp. 41626-41633, 2004.

[150] C. M. Shanahan, N. R. B. Cary, J. K. Osbourn, and P. L. Weissberg, "Identification of osteoglycin as a component of the vascular matrix: differential expression by vascular smooth muscle cells during neointima formation and in atherosclerotic plaques," Arteriosclerosis, Thrombosis, and Vascular Biology, vol. 17, no. 11, pp. 2437-2447, 1997.

[151] B. Fernández, A. Kampmann, F. Pipp, R. Zimmermann, and W. Schaper, "Osteoglycin expression and localization in rabbit tissues and atherosclerotic plaques," Molecular and Cellular Biochemistry, vol. 246, no. 1-2, pp. 3-11, 2003.

[152] X. N. Cui, J. W. Tang, B. Song, B. Wang, S. Y. Chen, and L. Hou, "High expression of osteoglycin decreases gelatinase activity of murine hepatocarcinoma Hca-F cells," World Journal of Gastroenterology, vol. 15, no. 48, pp. 6117-6122, 2009.

[153] X. Cui, B. Song, L. Hou, Z. Wei, and J. Tang, "High expression of osteoglycin decreases the metastatic capability of mouse hepatocarcinoma Hca-F cells to lymph nodes," Acta Biochimica et Biophysica Sinica, vol. 40, no. 4, pp. 349-355, 2008.

[154] E. S. Tasheva and G. W. Conrad, "Interferon- $\gamma$ regulation of the human mimecan promoter," Molecular Vision, vol. 9, pp. 277-287, 2003.

[155] H. Bentz, R. M. Nathan, D. M. Rosen et al., "Purification and characterization of a unique osteoinductive factor from bovine bone," Journal of Biological Chemistry, vol. 264, no. 34, pp. 20805-20810, 1989.

[156] L. Madisen, M. Neubauer, G. Plowman et al., "Molecular cloning of a novel bone-forming compound: osteoinductive factor," DNA and Cell Biology, vol. 9, no. 5, pp. 303-309, 1990. 
[157] J. R. Dasch, D. R. Pace, P. D. Avis, H. Bentz, and S. Chu, "Characterization of monoclonal antibodies recognizing bovine bone osteoglycin," Connective Tissue Research, vol. 30, no. 1, pp. 11-21, 1993.

[158] T. Xu, P. Bianco, L. W. Fisher et al., "Targeted disruption of the biglycan gene leads to an osteoporosis-like phenotype in mice," Nature Genetics, vol. 20, no. 1, pp. 78-82, 1998.

[159] S. Hamajima, K. Hiratsuka, M. Kiyama-Kishikawa et al., "Effect of low-level laser irradiation on osteoglycin gene expression in osteoblasts," Lasers in Medical Science, vol. 18, no. 2, pp. 78-82, 2003.

[160] A. Aziz, T. Miyake, K. A. Engleka, J. A. Epstein, and J. C. McDermott, "Menin expression modulates mesenchymal cell commitment to the myogenic and osteogenic lineages," Developmental Biology, vol. 332, no. 1, pp. 116-130, 2009.

[161] M. T. Prosperi, D. Ferbus, I. Karczinski, and G. Goubin, “A human cDNA corresponding to a gene overexpressed during cell proliferation encodes a product sharing homology with amoebic and bacterial proteins," Journal of Biological Chemistry, vol. 268, no. 15, pp. 11050-11056, 1993.

[162] T. Ishii, M. Yamada, H. Sato et al., "Cloning and characterization of a $23-\mathrm{kDa}$ stress-induced mouse peritoneal macrophage protein," Journal of Biological Chemistry, vol. 268, no. 25, pp. 18633-18636, 1993.

[163] H. Z. Chae, K. Robison, L. B. Poole, G. Church, G. Storz, and S. G. Rhee, "Cloning and sequencing of thiol-specific antioxidant from mammalian brain: alkyl hydroperoxide reductase and thiol-specific antioxidant define a large family of antioxidant enzymes," Proceedings of the National Academy of Sciences of the United States of America, vol. 91, no. 15, pp. 7017-7021, 1994.

[164] T. Yanagawa, S. Iwasa, T. Ishii et al., "Peroxiredoxin I expression in oral cancer: a potential new tumor marker," Cancer Letters, vol. 156, no. 1, pp. 27-35, 2000.

[165] J. W. Chang, H. B. Jeon, J. H. Lee et al., "Augmented expression of peroxiredoxin I in lung cancer," Biochemical and Biophysical Research Communications, vol. 289, no. 2, pp. 507-512, 2001.

[166] H. J. Kim, H. Z. Chae, Y. J. Kim et al., "Preferential elevation of Prx I and Trx expression in lung cancer cells following hypoxia and in human lung cancer tissues," Cell Biology and Toxicology, vol. 19, no. 5, pp. 285-298, 2003.

[167] V. L. Kinnula, P. Pääkkö, and Y. Soini, “Antioxidant enzymes and redox regulating thiol proteins in malignancies of human lung," FEBS Letters, vol. 569, no. 1-3, pp. 1-6, 2004.

[168] S. T. Lehtonen, A. M. Svensk, Y. Soini et al., "Peroxiredoxins, a novel protein family in lung cancer," International Journal of Cancer, vol. 111, no. 4, pp. 514-521, 2004.

[169] J. W. Chang, S. H. Lee, J. Y. Jeong et al., "Peroxiredoxin-I is an autoimmunogenic tumor antigen in non-small cell lung cancer," FEBS Letters, vol. 579, no. 13, pp. 2873-2877, 2005.

[170] J. H. Kim, P. N. Bogner, N. Ramnath, Y. Park, J. Yu, and Y. M. Park, "Elevated peroxiredoxin 1, but not NF-E2-related factor 2, is an independent prognostic factor for disease recurrence and reduced survival in stage I non-small cell lung cancer," Clinical Cancer Research, vol. 13, no. 13, pp. 38753882, 2007.

[171] J. H. Kim, P. N. Bogner, S. H. Baek et al., "Up-regulation of peroxiredoxin 1 in lung cancer and its implication as a prognostic and therapeutic target," Clinical Cancer Research, vol. 14 , no. 8, pp. 2326-2333, 2008.
[172] S. Y. Kim, T. J. Kim, and K. Y. Lee, "A novel function of peroxiredoxin $1(\operatorname{Prx}-1)$ in apoptosis signal-regulating kinase 1 (ASK1)-mediated signaling pathway," FEBS Letters, vol. 582, no. 13, pp. 1913-1918, 2008.

[173] J. Shen, M. D. Person, J. Zhu, J. L. Abbruzzese, and D. Li, "Protein expression profiles in pancreatic adenocarcinoma compared with normal pancreatic tissue and tissue affected by pancreatitis as detected by two-dimensional gel electrophoresis and mass spectrometry," Cancer Research, vol. 64, no. 24, pp. 9018-9026, 2004.

[174] Y. Qi, J. F. Chiu, L. Wang, D. L. W. Kwong, and Q. Y. He, "Comparative proteomic analysis of esophageal squamous cell carcinoma," Proteomics, vol. 5, no. 11, pp. 2960-2971, 2005.

[175] M. F. Chen, W. C. Chen, C. T. Wu et al., "p53 status is a major determinant of effects of decreasing peroxiredoxin I expression on tumor growth and response of lung cancer cells to treatment," International Journal of Radiation Oncology Biology Physics, vol. 66, no. 5, pp. 1461-1472, 2006.

[176] M. F. Chen, P. C. Keng, H. Shau et al., "Inhibition of lung tumor growth and augmentation of radiosensitivity by decreasing peroxiredoxin I expression," International Journal of Radiation Oncology Biology Physics, vol. 64, no. 2, pp. 581591, 2006.

[177] Y.-J. Kim, W.-S. Lee, C. Ip, H.-Z. Chae, E.-M. Park, and Y.M. Park, "Prx1 suppresses radiation-induced c-Jun NH2terminal kinase signaling in lung cancer cells through interaction with the glutathione S-transferase Pi/c-Jun NH2terminal kinase complex," Cancer Research, vol. 66, no. 14, pp. 7136-7142, 2006.

[178] Y. Manevich, T. Sweitzer, J. H. Pak, S. I. Feinstein, V. Muzykantov, and A. B. Fisher, "1-Cys peroxiredoxin overexpression protects cells against phospholipid peroxidationmediated membrane damage," Proceedings of the National Academy of Sciences of the United States of America, vol. 99, no. 18, pp. 11599-11604, 2002.

[179] J. H. Pak, Y. Manevich, H. S. Kim, S. I. Feinstein, and A. B. Fisher, "An antisense oligonucleotide to 1-cys peroxiredoxin causes lipid peroxidation and apoptosis in lung epithelial cells," Journal of Biological Chemistry, vol. 277, no. 51, pp. 49927-49934, 2002.

[180] S. W. Shan, M. K. Tang, D. Q. Cai et al., "Comparative proteomic analysis identifies protein disulfide isomerase and peroxiredoxin 1 as new players involved in embryonic interdigital cell death," Developmental Dynamics, vol. 233, no. 2, pp. 266-281, 2005.

[181] H. Shibayama, E. Takai, I. Matsumura et al., "Identification of a cytokine-induced antiapoptotic molecule anamorsin essential for definitive hematopoiesis," Journal of Experimental Medicine, vol. 199, no. 4, pp. 581-592, 2004.

[182] Z. Hao, T. Qiao, X. Jin, X. Li, J. Gao, and D. Fan, "Preparation and characterization of a specific monoclonal antibody against CIAPIN1," Hybridoma, vol. 24, no. 3, pp. 141-145, 2005.

[183] X. Li, K. Wu, and D. Fan, "CIAPIN1 as a therapeutic target in cancer," Expert Opinion on Therapeutic Targets, vol. 14, no. 6, pp. 603-610, 2010.

[184] Z. Hao, X. Li, T. Qiao, S. Li, Y. Lv, and D. Fan, "Downregulated expression of CIAPIN1 may contribute to gastric carcinogenesis by accelerating cell proliferation and promoting cell cycle progression," Cancer Biology and Therapy, vol. 8, no. 11, pp. 1064-1070, 2009. 
[185] L. He, H. Wang, H. Jin et al., "CIAPIN1 inhibits the growth and proliferation of clear cell renal cell carcinoma," Cancer Letters, vol. 276, no. 1, pp. 88-94, 2009.

[186] X. Zheng, Y. Zhao, X. Wang et al., "Decreased expression of CIAPIN1 is correlated with poor prognosis in patients with esophageal squamous cell carcinoma," Digestive Diseases and Sciences, vol. 55, no. 12, pp. 3408-3414, 2010.

[187] H. Shi, Y. Zhou, H. Liu et al., "Expression of CIAPIN1 in human colorectal cancer and its correlation with prognosis," BMC Cancer, vol. 10, article 477, 2010.

[188] X. Li, Z. Hao, R. Fan et al., "CIAPIN1 inhibits gastric cancer cell proliferation and cell cycle progression by downregulating CyclinD1 and upregulating P27," Cancer Biology and Therapy, vol. 6, no. 10, pp. 1539-1545, 2007. 

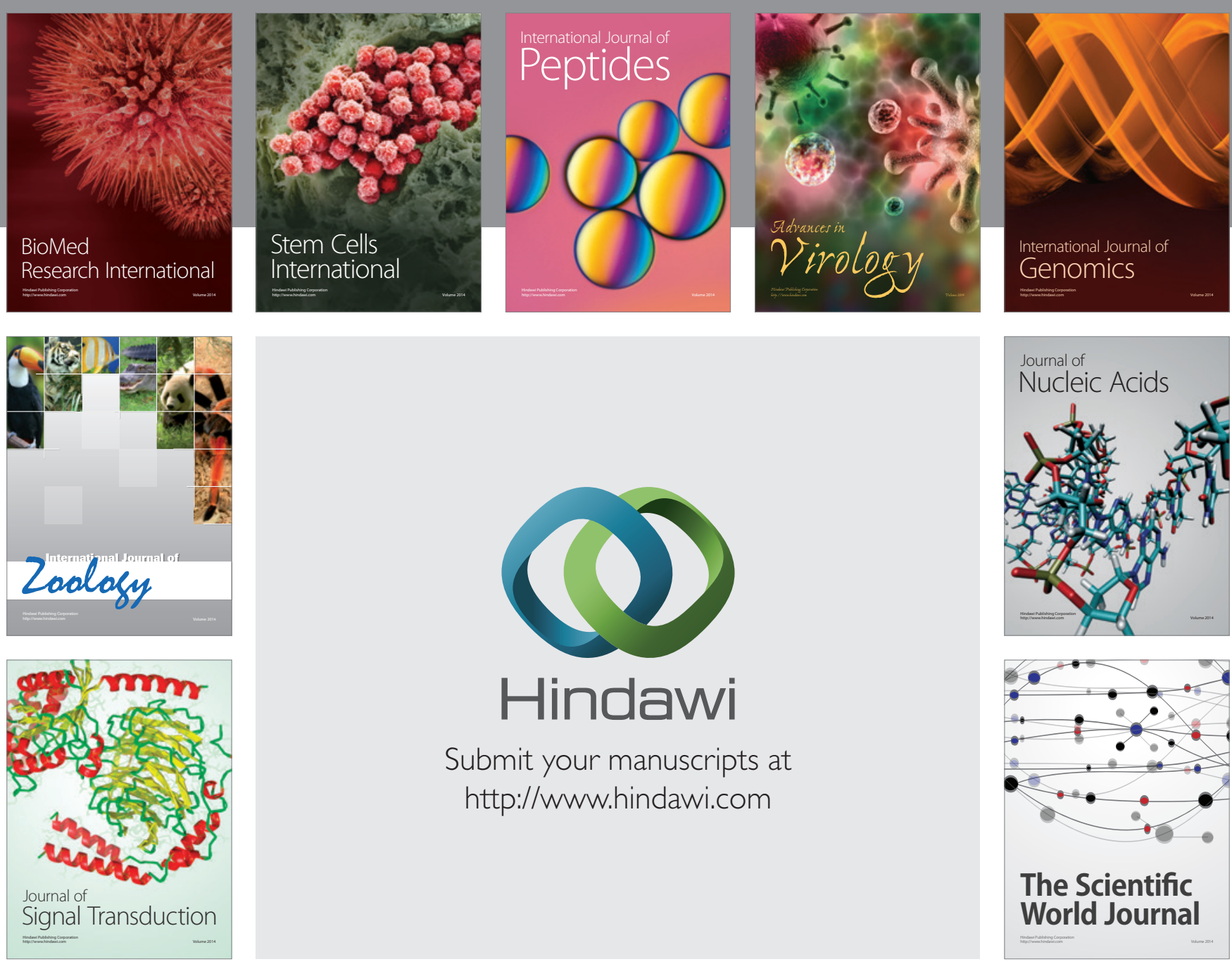

Submit your manuscripts at

http://www.hindawi.com
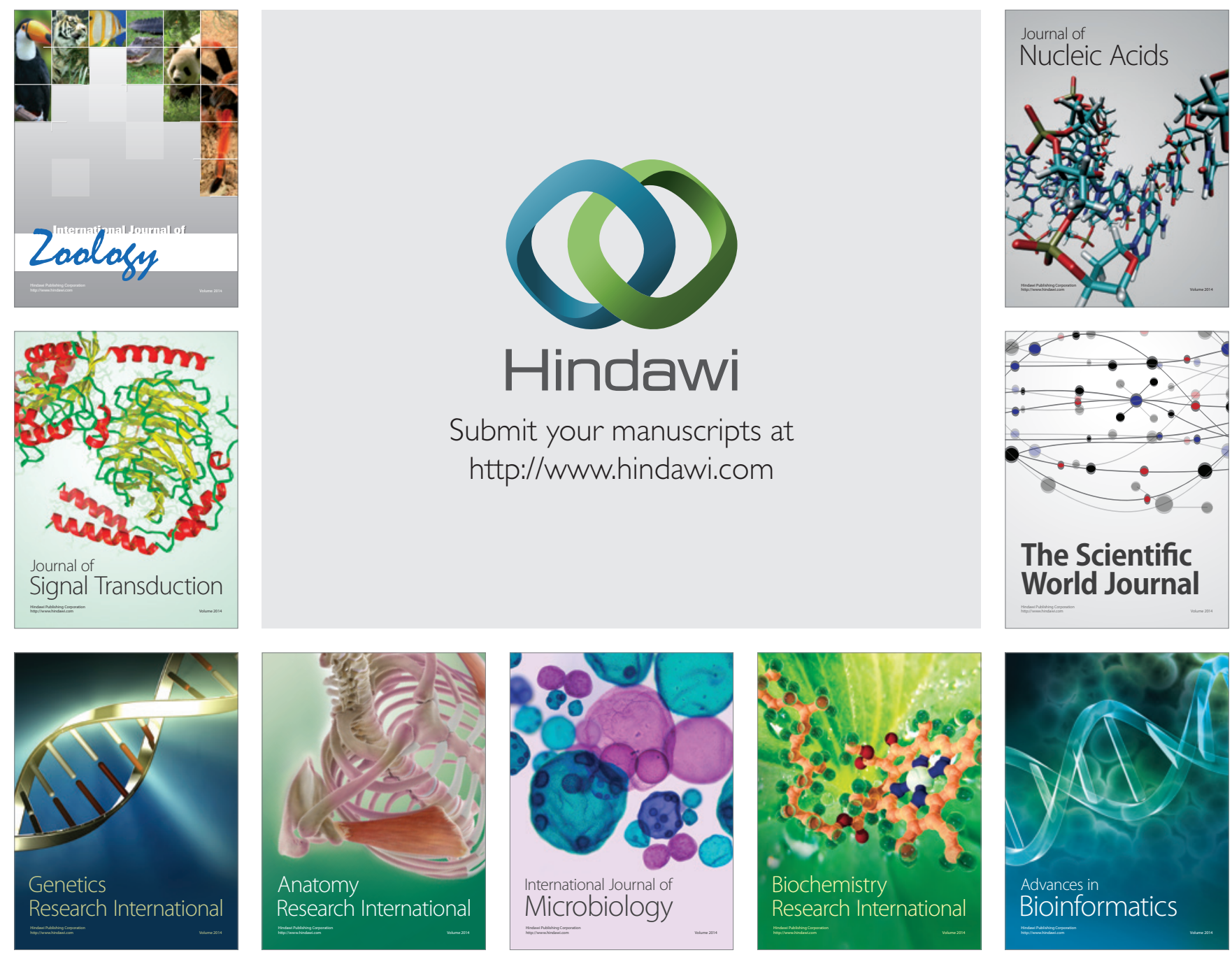

The Scientific World Journal
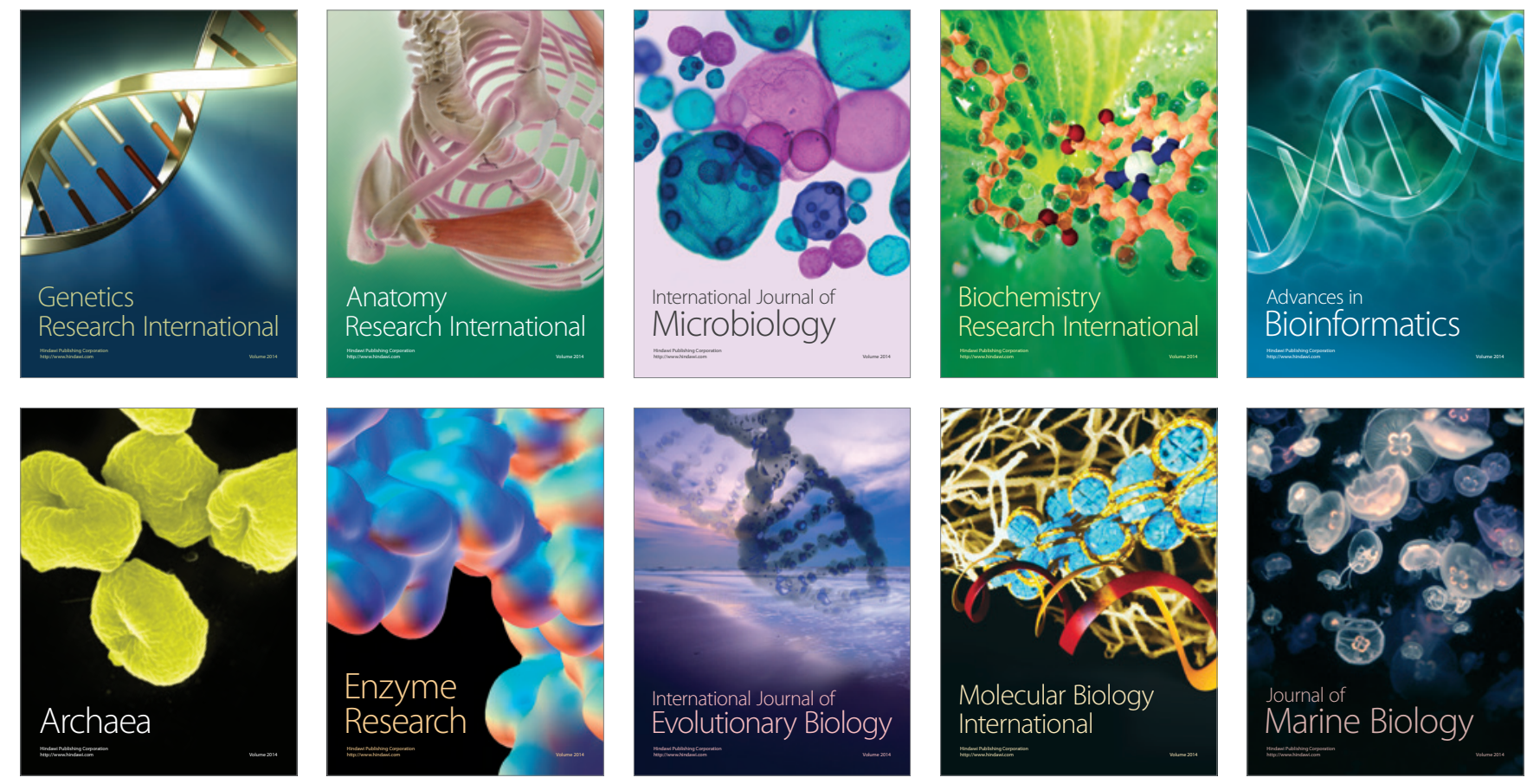